\title{
Periodontal Diseases and COVID-19: A Scoping Review
}

\author{
Lisa Basso ${ }^{1, *} \quad$ Doriane Chacun ${ }^{1,2,3, *} \quad$ Kadiatou Sy, ${ }^{2,3,4}$ \\ ${ }^{1}$ Laboratoire des Multimatériaux et Interfaces, Claude Bernard \\ University Lyon 1, Villeurbanne, France \\ 2 Faculty of Odontology, Claude Bernard University Lyon 1, Lyon, \\ France \\ ${ }^{3}$ Hospices Civils de Lyon, Service de Consultations et de Traitements
}

Brigitte Grosgogeat ${ }^{1,2,5}$ Kerstin Gritsch ${ }^{1,2,3, \odot}$ Address for correspondence Kerstin Gritsch, DDS, PhD, Faculty of Odontology, Claude Bernard University Lyon 1, 11 rue Guillaume Paradin, 69372 Lyon cedex 08, France (e-mail: kerstin.gritsch@univ-lyon1.fr).

${ }^{*}$ These are the co-first authors for this article.

published online September 9, 2021
The aim of this scoping review was to present the existing literature regarding the relationship between periodontal diseases and coronavirus disease 2019 (COVID-19). The Preferred Reporting Items for Systematic Reviews and Meta-Analyses (PRISMA) extension for scoping review guidelines was followed. Articles were retrieved from PubMed/MEDLINE and Scopus databases and screened to include studies relating severe acute respiratory syndrome coronavirus 2 (SARS-CoV-2) or COVID-19 to periodontal cells and/or tissues and/or diseases. Twenty-five papers were included; consisting of six reviews, seven original articles, six short reports, four letters to the editor, one commentary, and one case report. The articles were allocated to three different topics: (i) hypotheses on the relationship between periodontal diseases and COVID-19; (ii) risk factors and comorbidities common to periodontitis and COVID-19; (iii) periodontal manifestations of COVID-19. Certain molecules (angiotensin-converting enzyme-2, furin, cathepsin, TMPRSS2...) that are found at a high level in periodontal tissues, particularly in patients with periodontitis, are involved in the mechanism of entry of SARS-CoV-2 into cells. Periodontopathic bacteria could also play a direct role in the mechanism of entry of SARS-CoV-2 by cleaving the S-protein, and the cytokines produced during periodontitis could add to the cytokine storm found in the severe forms of COVID-19. It thus appears that the treatment of periodontitis, which allows a reduction in periodontopathic bacteria and of the local and systemic inflammation state, could be part of a strategy to prevent the development of severe forms of COVID-19.

- periodontitis

DOI https://doi.org/

$10.1055 / \mathrm{s}-0041-1729139$ ISSN $1305-7456$
C 2021. European Journal of Dentistry

This is an open access article published by Thieme under the terms of the Creative Commons Attribution-NonDerivative-NonCommercial-License, permitting copying and reproduction so long as the original work is given appropriate credit. Contents may not be used for commercial purposes, or adapted, remixed, transformed or built upon. (https://creativecommons.org/licenses/by-nc-nd/4.0/).

Thieme Medical and Scientific Publishers Pvt. Ltd. A-12, 2nd Floor, Sector 2, Noida-201301 UP, India 


\section{Introduction}

Coronavirus disease 2019 (COVID-19), a disease that provokes severe acute respiratory syndrome, ${ }^{1}$ was first identified in the province of Wuhan, China, in December 20192 and as of February 17, 2021, a total of 109,217,366 confirmed cases, including 2,413,912 deaths, have been reported to the World Health Organization (WHO). ${ }^{3}$ Among the factors that increase the risk of severe outcomes and mortality, ${ }^{4}$ cardiovascular diseases, cancer, obesity, and diabetes have also been reported to be associated with periodontal diseases. ${ }^{5-10}$ In this context, the potential relationship between COVID-19 and periodontal diseases has become of major interest and many papers have been published on this issue. The aim of the present scoping review was not only to present the published data regarding potential relationships between periodontal diseases and COVID-19 but also to highlight any gaps in the existing literature.

\section{Materials and Methods}

The Preferred Reporting Items for Systematic Reviews and Meta-Analyses (PRISMA) extension for scoping review have been used as a guideline throughout the manuscript. ${ }^{11}$ A literature search was performed using two electronic databases (MEDLINE/PubMed and Scopus). Eligibility criteria were studies on severe acute respiratory syndrome coronavirus 2 (SARS-CoV-2) or COVID-19; relating SARS-CoV-2 or COVID-19 to periodontal cells and/or tissues and/or diseases; published until the December 31, 2020.

The following literature search was conducted using PubMed and adapted to Scopus. The terms used in the search were limited on "Title and Abstract": (Periodont*) AND (COVID OR coronavirus).

\section{Selection of Sources of Evidence}

The titles and abstracts of identified records were screened independently by two reviewers (LB and KG) after removal of duplicates; disagreements were resolved through discussion. The full texts of all the abstracts in accordance with the focus question were collected and reviewed; disagreements were resolved through discussion.

\section{Data Charting Process}

A data-charting form was jointly developed by two reviewers (LB and KG) to determine which variables to extract. For each paper, the following items were noted: article type, publication date, proposed mechanism of SARS-CoV-2 entry, proposed mechanism of how periodontitis might influence the entry of SARS-CoV-2 into cells or might worsen COVID-19, proposed antiviral targets, risk factors, or comorbidities common to periodontitis and COVID-19.

Two reviewers ( $\mathrm{LB}$ and $\mathrm{KG}$ ) independently charted the data and discussed the results.

\section{Results}

A total of 119 records were identified from the databases and 3 from other sources; of these 41 were duplicates and were removed. The title and abstract of 81 records were assessed, 50 were excluded. The remaining 31 underwent full-text examination; 25 studies were finally included in the review ( - Fig. 1). ${ }^{12-36}$ Among the six articles excluded after full-text assessment, one focused on the association between periodontitis and respiratory diseases in general and was not specific to COVID-19, ${ }^{37}$ one focused on the oral manifestations in COVID-19 but was not specific to periodontal diseases, ${ }^{38}$ one reviewed the risks of periodontal procedures in terms of aerosolization and transmission of the SARS-CoV- $2,^{39}$ and two illustrated the association between periodontitis and COVID-19 through a study included in the review ${ }^{40,41}$; the full-text of the sixth article was not available and the authors were contacted but have not provided the paper at the time of writing. ${ }^{42}$

To give structure to this review, the papers were classified into three topics: (i) hypotheses on the relationship between periodontal diseases and COVID-19, (ii) risk factors and comorbidities common to periodontitis and COVID-19, and (iii) periodontal manifestations of COVID-19.

\section{Hypotheses on the Relationship between Periodontal Diseases and COVID-19 \\ Study Characteristics}

Among the 22 studies related to this topic, 15 were nonexperimental studies $12,15-19,21,23-25,27,28,30,32,35$; there were seven experimental reports. ${ }^{13,14,26,31,33,34,36}$ For 16, the type of article was

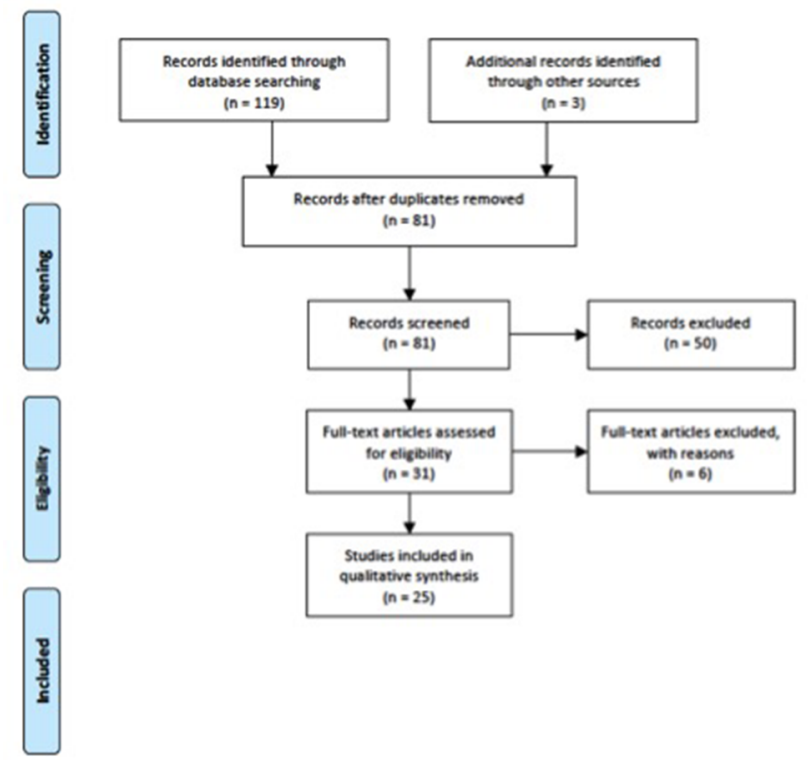

Fig. 1 Preferred Reporting Items for Systematic Reviews and Meta-Analyses (PRISMA) flow diagram. 
clearly indicated; seven were original articles, $13,14,26,31,33,34,36$ four were letters to the editor, ${ }^{17,18,25,30}$ four were revi ews, ${ }^{24,28,32,35}$ and one was a "commentary." ${ }^{27}$ Among the six for which this was not clearly indicated, we considered that five were short reports ${ }^{12,15,16,19,21}$ - one of which reported an ongoing clinical trial, ${ }^{16}$ and one was a review. ${ }^{23}$ The information relating to the topic found in the papers was the SARS-CoV-2 entry mechanism, ${ }^{12-14,16,18,21,24-28,30-32,36}$ the mechanism of how periodontitis might influence the entry of SARS-CoV-2 into cells or might worsen COVID-19, ${ }^{15-19,21,23-28,30,32-36}$ and antiviral targets to treat COVID-19 ( - Table 1). ${ }^{14,18,24,27}$

\section{SARS-CoV-2 Entry Mechanism}

The main reported receptor allowing SARS-CoV-2 for entry in to human cells is angiotensin-converting enzyme-2 (ACE-2). ${ }^{13,14,16,18,21,24-28,30,32,36}$ The latter is present in several tissues including lungs, nasopharyngeal mucosa, salivary glands, and oral mucosa. . $^{13,14,16,18,24,27,30,36}$ Within the oral mucosa, ACE-2 is mainly expressed not only by epithelial cells but also by fibroblasts, ${ }^{16} \mathrm{~T}$ cells, and B cells; it is not only detected in the lip, tongue, and buccal mucosa but also in the gingival (stratified squamous epithelium) and palatal tissue. ${ }^{13,14,18,26}$

Table 1 Characteristics of the studies hypothesizing a relationship between periodontal diseases and COVID-19 ( $n=22)$

\begin{tabular}{|c|c|c|c|c|c|}
\hline Authors & Article type & Publication date & $\begin{array}{l}\text { SARS-CoV-2 entry } \\
\text { mechanism }\end{array}$ & Influence of periodontitis & $\begin{array}{l}\text { Antiviral } \\
\text { targets }\end{array}$ \\
\hline Roganovic $^{36}$ & Original article & December 14, 2020 & $\begin{array}{l}\text { Micro-RNA-146a and -155 } \\
\text { may enhance expression } \\
\text { of ACE-2 }\end{array}$ & $\begin{array}{l}\text { Micro-RNA-146a and - } 155 \\
\text { increased in the oral cavity } \\
\text { during periodontitis }\end{array}$ & - \\
\hline Gofur ${ }^{35}$ & Review & November 30, 2020 & - & $\begin{array}{l}\text { Periodontopathic bacteria } \\
\text { could increase the severity of } \\
\text { COVID-19 } \\
\text { (risk of bacterial superinfection) } \\
\text { Periodontal pockets may be a } \\
\text { reservoir for SARS-CoV-2 }\end{array}$ & - \\
\hline $\begin{array}{l}\text { Fernandes } \\
\text { Matuck et al }{ }^{34}\end{array}$ & Original article & November 26, 2020 & - & $\begin{array}{l}\text { Presence of SARS-CoV-2 in } \\
\text { periodontal tissue in deceased } \\
\text { COVID- } 19 \text { patients }\end{array}$ & - \\
\hline Larvin et $\mathrm{al}^{33}$ & Original article & November 23, 2020 & - & $\begin{array}{l}\text { Periodontitis may be associated } \\
\text { with COVID-19 and increase the } \\
\text { risk of death }\end{array}$ & - \\
\hline Takahashi et al ${ }^{32}$ & Review & November 12, 2020 & $\begin{array}{l}\text { Binding of the } S \text { protein to } \\
\text { ACE-2 } \\
\text { S protein cleaved by } \\
\text { TMPRSS } 2 \text { and furin, and } \\
\text { may also be cleaved by } \\
\text { the proteases produced by } \\
\text { periodontopathic bacteria }\end{array}$ & $\begin{array}{l}\text { Aspiration of periodontopathic } \\
\text { bacteria induces ACE- } 2 \text { expres- } \\
\text { sion, cytokines production in } \\
\text { the lower respiratory tract and } \\
\text { degradation of the } S \text { protein }\end{array}$ & - \\
\hline Gupta et $a^{31}$ & Original article & November 2, 2020 & $\begin{array}{l}\text { SARS-CoV-2 identified in } \\
\text { the gingival crevicular fluid }\end{array}$ & - & - \\
\hline Elisetti ${ }^{30}$ & $\begin{array}{l}\text { Letter to the } \\
\text { editor }\end{array}$ & November 1, 2020 & $\begin{array}{l}\text { Presence of ACE- } 2 \text { and } \\
\text { TMPRSS } 2 \text { in salivary glands }\end{array}$ & $\begin{array}{l}\text { Presence of SARS-CoV-2 in } \\
\text { saliva; breach of the periodontal } \\
\text { pocket epithelium may be an } \\
\text { entry point for the virus }\end{array}$ & - \\
\hline Mancini et al28 & Review & September 8, 2020 & ACE-2 & $\begin{array}{l}\text { Low ACE-2 levels in periodon- } \\
\text { tal patients as for COVID-19 } \\
\text { patients (reduced ACE- } 2 \text { levels } \\
\text { at the cell surface due to an } \\
\text { ACE-2-SARS-CoV-2 connection) }\end{array}$ & - \\
\hline Kara et $\mathrm{al}^{27}$ & Commentary & August 24, 2020 & $\begin{array}{l}\text { Presence of ACE- } 2 \text { in oral } \\
\text { mucosa } \\
\text { Gal- } 3 \text { may increase } \\
\text { immune response and viral } \\
\text { attachment }\end{array}$ & $\begin{array}{l}\text { Increased level of Gal-3 } \\
\text { associated with the severity of } \\
\text { periodontitis }\end{array}$ & $\begin{array}{l}\text { Inhibition of } \\
\text { Gal-3 may } \\
\text { disrupt the } \\
\text { SARS-CoV-2 } \\
\text { attachment }\end{array}$ \\
\hline Sakaguchi et a ${ }^{26}$ & Original article & August 20, 2020 & $\begin{array}{l}\text { Presence of ACE-2, } \\
\text { TMPRSS2 and furin in the } \\
\text { oral cavity (tongue epithe- } \\
\text { lium, taste buds, gingiva } \\
\text { and sulcus epithelium, } \\
\text { submandibular glands) }\end{array}$ & $\begin{array}{l}\text { Periodontal pocket epithelium } \\
\text { may be a focal point of infection } \\
\text { to SARS-CoV-2 }\end{array}$ & - \\
\hline
\end{tabular}


Periodontal Diseases and COVID-19 Basso et al. 771

Table 1 (Continued)

\begin{tabular}{|c|c|c|c|c|c|}
\hline Authors & Article type & Publication date & $\begin{array}{l}\text { SARS-CoV-2 entry } \\
\text { mechanism }\end{array}$ & Influence of periodontitis & $\begin{array}{l}\text { Antiviral } \\
\text { targets }\end{array}$ \\
\hline $\begin{array}{l}\text { Pedrosa } \\
\text { and Neves } \\
\text { Nogueira }^{25}\end{array}$ & $\begin{array}{l}\text { Letter to the } \\
\text { editor }\end{array}$ & August 7, 2020 & ACE- 2 and TMPRSS2 & $\begin{array}{l}\text { Oxidative stress, as a link } \\
\text { between diabetes and perio- } \\
\text { dontal disease, may play a part } \\
\text { in COVID-19 infection }\end{array}$ & - \\
\hline Bertolini et $\mathrm{a}^{24}$ & Review & July 6,2020 & $\begin{array}{l}\text { Presence of ACE-2 in the } \\
\text { nasopharyngeal mucosa, } \\
\text { salivary cells and oral } \\
\text { epithelial cells. } \\
\text { Role of furin and cathepsin } \\
\text { L in enabling the } \\
\text { SARS-CoV-2 to bind ACE-2 }\end{array}$ & $\begin{array}{l}\text { High viral load of SARS-CoV-2 in } \\
\text { the crevicular fluid }\end{array}$ & $\begin{array}{l}\text { TMPRSS2 } \\
\text { inhibitor is } \\
\text { able to block } \\
\text { the SARS- } \\
\text { CoV-2 entry } \\
\text { into cells }\end{array}$ \\
\hline Sampson et $a^{23}$ & Review & June 26, 2020 & - & $\begin{array}{l}\text { Periodontopathic bacteria } \\
\text { (Prevotella, Staphylococcus, } \\
\text { Fusobacterium) } \\
\text { present in the metagenome of } \\
\text { patients severely infected with } \\
\text { SARS-CoV-2 }\end{array}$ & - \\
\hline Pfützner et $a^{21}$ & Short report & June 7,2020 & $\begin{array}{l}\text { ACE-2 highly expressed in } \\
\text { oral cavity }\end{array}$ & $\begin{array}{l}\text { Detectable SARS-CoV-2 } \\
\text { concentrations found in saliva; } \\
\text { ulceration of the gingival } \\
\text { epithelium during periodontitis } \\
\text { may increase the risk of invasion }\end{array}$ & - \\
\hline $\begin{array}{l}\text { Gupta and } \\
\text { Sahni }{ }^{19}\end{array}$ & Short report & June 7, 2020 & - & $\begin{array}{l}\text { Interferon } \alpha \text { implicated in the } \\
\text { stimulation of NETs release } \\
\text { (higher in periodontal patients); } \\
\text { NETs may be implicated in the } \\
\text { "cytokine storm" described in } \\
\text { advanced stages of COVID-19 }\end{array}$ & - \\
\hline $\begin{array}{l}\text { Madapusi Balaji } \\
\text { et al }{ }^{18}\end{array}$ & $\begin{array}{l}\text { Letter to the } \\
\text { editor }\end{array}$ & June 1, 2020 & $\begin{array}{l}\text { Presence of ACE- } 2 \text { in oral } \\
\text { mucosa including tongue, } \\
\text { buccal mucosa and gingiva } \\
\text { Role of furin, cathepsin B/L } \\
\text { and TMPRSS2 in SARS- } \\
\text { CoV-2 entry into cells }\end{array}$ & $\begin{array}{l}\text { Furin and cathepsin L levels } \\
\text { elevated in patients with } \\
\text { periodontitis }\end{array}$ & $\begin{array}{l}\text { Melatonin } \\
\text { inhibits } \\
\text { cathepsin L }\end{array}$ \\
\hline $\begin{array}{l}\text { Sahni and } \\
\text { Gupta }{ }^{17}\end{array}$ & $\begin{array}{l}\text { Letter to the } \\
\text { editor }\end{array}$ & May 30, 2020 & - & $\begin{array}{l}\text { Cytokines levels elevated } \\
\text { in both periodontitis and } \\
\text { COVID-19 }\end{array}$ & - \\
\hline Badran et al $^{16}$ & Short report & May 30, 2020 & $\begin{array}{l}\text { Presence of ACE-2 in sali- } \\
\text { vary glands cells, gingival } \\
\text { and periodontal ligament } \\
\text { fibroblasts } \\
\text { Presence of furin in oral } \\
\text { epithelial cells } \\
\text { SARS-CoV-2 could infect } \\
\text { cells by binding to CD147 } \\
\text { instead of ACE-2 }\end{array}$ & $\begin{array}{l}\text { Periodontal pocket may be } \\
\text { a favorable environment for } \\
\text { SARS-CoV-2 replication; virus } \\
\text { could reach the oral cavity and } \\
\text { mix with saliva, or migrate } \\
\text { systemically via the capillary } \\
\text { periodontal complex. } \\
\text { Gingival epithelium expression } \\
\text { of CD147 increased in patients } \\
\text { with periodontitis }\end{array}$ & - \\
\hline Botros et al ${ }^{15}$ & Short report & May 29, 2020 & - & $\begin{array}{l}\text { Secretion of pro-inflammatory } \\
\text { cytokines during periodontitis } \\
\text { can promote adhesion to lung } \\
\text { epithelium and lung coloniza- } \\
\text { tion by respiratory pathogens }\end{array}$ & - \\
\hline
\end{tabular}

(Continued) 
Table 1 (Continued)

\begin{tabular}{|l|l|l|l|l|}
\hline Authors & Article type & Publication date & $\begin{array}{l}\text { SARS-CoV-2 entry } \\
\text { mechanism }\end{array}$ & Influence of periodontitis \\
\hline Zhong et al ${ }^{14}$ & Original article & April 22, 2020 & $\begin{array}{l}\text { Antiviral } \\
\text { targets } \\
\text { in oral mucosal tissues } \\
\text { (epithelial layers, partly } \\
\text { expressed in fibroblasts) } \\
\text { Two possible routes for } \\
\text { SARS-CoV-2 invasion: } \\
\text { binding to the ACE-2 recep- } \\
\text { tor and fusion with cell } \\
\text { membrane activated by } \\
\text { furin protease }\end{array}$ & Furin \\
\hline Xu et al ${ }^{13}$ & Original article & February 24, 2020 & $\begin{array}{l}\text { Expression of ACE-2 on } \\
\text { the mucosa of oral cavity } \\
\text { (higher in tongue than } \\
\text { buccal or gingival tissues); } \\
\text { the oral cavity might be } \\
\text { a potential risk route of } \\
\text { SARS-CoV-2 infection }\end{array}$ & - \\
\hline $\begin{array}{l}\text { Kadkhodazadeh } \\
\text { et al }{ }^{12}\end{array}$ & Short report & January 10, 2020 & $\begin{array}{l}\text { SARS-CoV-2 identified } \\
\text { in the saliva of infected } \\
\text { patients }\end{array}$ & - \\
\hline
\end{tabular}

Abbreviations: ACE-2, angiotensin-converting enzyme-2; COVID-19, coronavirus disease 2019; Gal-3, galectin-3; SARS-CoV-2, severe acute respiratory syndrome coronavirus 2 .

One of the hypotheses is that furin, cathepsin, and TMPRSS2 proteases allow the entry of SARS-CoV-2 into cells. ${ }^{14,16,18,24-26,30,32}$ Furin is thought to precleave the spike protein (S-protein) of coronavirus into two subunits (S1 and S2) allowing S1 to attach itself to ACE-2. ${ }^{18,24}$ Then, the virus fuses with the host cells in two ways: endosomal fusion mediated by cysteine protease cathepsin $\mathrm{B} / \mathrm{L}$ and plasma membrane fusion mediated by serine protease TMPRSS2. ${ }^{18}$ In addition, Roganovic, who constructed an in silico model around the mechanism involving ACE-2 and furin/TMPRSS2, reported that microRNA-146 and -155 seem to be widely involved in the regulation of SARS-CoV-2 oral cellular entry factors and may enhance expression of ACE- 2 and modulate genes involved in host immunity. ${ }^{36}$ Another infection route that has been suggested also involves the S-protein but through binding to the cluster of differentiation 147 (CD-147). ${ }^{16}$

\section{How Do Periodontal Diseases Worsen COVID-19?}

Multiple papers try to explain the mechanism of how periodontitis worsens COVID-19. ${ }^{15-19,21,23-28,30,32-36}$ Among these, three mention the impact of cytokine release during periodontitis that may worsen the cytokine storm described in some symptomatic COVID-19 patients. ${ }^{17,19,32}$ Moreover, the cytokines produced during periodontitis can promote adhesion to lung epithelium and lung colonization by respiratory pathogens; in parallel, aspirated periodontopathic bacteria may also induce secretion of cytokines in the lower respiratory tract aggravating the symptoms of COVID-19. ${ }^{15,32}$

Other molecules or inflammatory mediators involved in periodontitis could also contribute to worsen COVID-19. For instance, the level of osteopontin is directly related to that of furin and cathepsin L, and thus could impact the mechanism of entry of SARS-CoV-2 into cells. ${ }^{18,24}$
Galectin-3 (Gal-3) is also suggested to play a role in both the severity of COVID-19 and periodontal diseases; an increased level in Gal-3 is associated with the level of severity of periodontal diseases and, as Gal-3 may cause an increased immune response and viral attachment, it could substantially impact the severity of COVID-19.27 Moreover, in periodontitis patients, gingival epithelium expression of CD-147 is increased ${ }^{16}$ potentially increasing SARS-CoV-2 entry into cells. Likewise, microRNA-146a and -155 are increased in the oral cavity during periodontitis, modulating host antiviral response. $^{36}$

One of the included articles focused on periodontal pathogens and their relationship with the severity of COVID-19; it was noted that periodontal pathogens increase the expression of ACE-2 and therefore offer more points of entry for the virus, and hypothesized that proteases of periodontopathic bacteria may cleavethe S-protein of the viral envelope of SARS-CoV-2 facilitating its entry into cells. ${ }^{32}$ In another paper, it is hypothesized that bacterial pathogens present in the oral cavity, in particular in the periodontal region, could increase the severity of COVID-19 due to the risk of bacterial superinfection. ${ }^{35}$

Five papers present the potential role of periodontal pockets as a reservoir for SARS-CoV-2. ${ }^{16,24,26,30,35}$ For some authors, ulceration of the gingival epithelium occurring during periodontitis could increase the risk of SARS-CoV-2 invasion..$^{21,30}$ This may be supported by a postmortem study that found SARS-CoV-2 in periodontal tissue in COVID-19 patients. ${ }^{34}$

From a more clinical point of view, a cohort study (UK Biobank cohort) found an increased risk of mortality following COVID-19 infection in people with periodontal disease, suggesting that periodontitis may be associated with the severity of COVID-19.33 
Table 2 Risk factors and comorbidities hypothesized to be common to periodontitis and COVID-19

\begin{tabular}{|l|l|l|l|}
\hline Authors & Article type & Publication date & Risk factors and comorbidities \\
\hline Botros et al $^{15}$ & Short report & May 29, 2020 & Chronic kidney disease, diabetes, liver disease, obesity \\
\hline Pfützner et al $^{21}$ & Short report & June 7, 2020 & Age, diabetes \\
\hline Pitones-Rubio et a ${ }^{22}$ & Review & June 19,2020 & $\begin{array}{l}\text { Age, asthma, cancer, cardiovascular disease and hyperten- } \\
\text { sion, chronic obstructive pulmonary disease, diabetes, human } \\
\text { immunodeficiency virus, liver disease, obesity, oral dysbiosis, } \\
\text { pregnancy, rheumatoid arthritis, sex, smoking }\end{array}$ \\
\hline $\begin{array}{l}\text { Pedrosa and Neves } \\
\text { Nogueira25 }\end{array}$ & $\begin{array}{l}\text { Letter to the } \\
\text { editor }\end{array}$ & August 7, 2020 & Diabetes \\
\hline $\begin{array}{l}\text { Räisänen et al }{ }^{29} \\
\text { Takahashi et al }\end{array}$ & Short report & September 12, 2020 & $\begin{array}{l}\text { Cancer, cardiovascular disease and hypertension, chronic kidney } \\
\text { disease, diabetes, respiratory disease }\end{array}$ \\
\hline Review & November 12, 2020 & $\begin{array}{l}\text { Cardiovascular disease, chronic obstructive pulmonary disease, } \\
\text { diabetes, pneumonia }\end{array}$ \\
\hline
\end{tabular}

Abbreviation: COVID-19, coronavirus disease 2019.

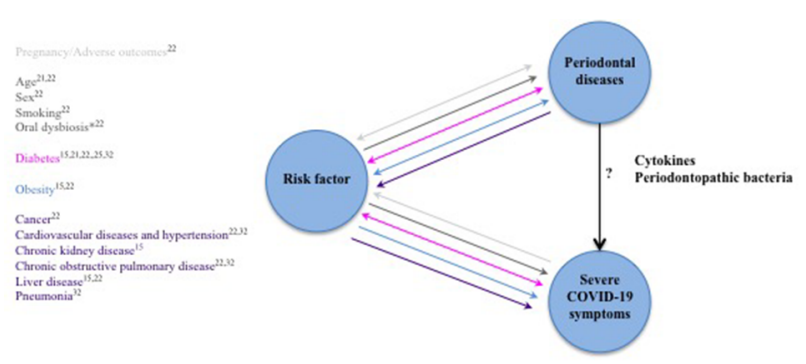

Fig. 2 Relationship between periodontal diseases and severe coronavirus disease 2019 (COVID-19) symptoms through suggested risk factors. Arrows indicate the onset or aggravation of diseases. ${ }^{*}$ Oral dysbiosis is the principal etiological factor of periodontitis.

\section{Antiviral Targets for COVID-19}

Antiviral targets have been proposed; these are involved in cellular entry mechanism of SARS-CoV-2, such as TMPRSS2, furin, and Gal-3, ${ }^{14,24,27}$ and others are involved in regulation of inflammation and oxidative stress, such as melatonin. ${ }^{18}$

\section{Periodontitis and COVID-19: Common Risk Factors and Comorbidities \\ Report Characteristics}

Six articles mentioned risk factors or comorbidities that may be common to COVID-19 and periodontal diseases. ${ }^{15,21,22,25,29,32}$ One was a letter to the editor, ${ }^{25}$ three were short reports, ${ }^{15,21,29}$ and two were reviews ( $\mathbf{- T a b l e ~ 2 ) . 2 2 , 3 2}$

\section{Hypothesized Common Risk Factors and Comorbidities}

Various parameters and diseases are presented as being able to constitute common risk factors, such as for example diabetes, obesity, or cardiovascular diseases (-Table 2); as are hypotheses of the relationships between these and periodontal diseases or severe COVID-19 symptoms suggesting a link between periodontal diseases and COVID-19. The most frequently proposed mechanism for this related to the cytokines released in response to periodontitis ${ }^{15,21,29,32}$ that could add to the cytokine storm encountered in severe forms of COVID-19. ${ }^{15,29}$ In addition, the presence of periodontopathic bacteria (oral dysbiosis) is presented as being able to facilitate cellular entry of SARS-CoV-2 (degradation of the S-protein) $)^{22,32}$ ( - Fig. 2) and known as being the principal etiological factor of periodontitis in the literature,,$^{5}$ and this is potentialized by a poor swallowing function in the elderly that increases the risk of periodontal pathogen aspiration. ${ }^{32}$

\section{Periodontal Manifestations of COVID-19}

One study was a case report of periodontal manifestations of COVID-19. ${ }^{20}$ A 35-year-old woman complained of gingival pain and bleeding characterized as edematous gingivae and necrotic interdental papillae; the final diagnosis was necrotizing gingivitis. Moreover, she had a fever and was a suspected case of COVID-19, but as testing was not available at the time, they could not confirm that she was positive for SARS-CoV-2. Another study, including 33 COVID-19 positive patients (including 20 who were asymptomatic), reported that 14 patients presented gum disease. ${ }^{31}$ However, it is not possible to determine whether gum disease was present prior to SARS-CoV-2 infection or whether it is a consequence of the infection.

A review article hypothesized that mild cases of COVID-19 might not show any oral manifestations, but in severe cases, persistent inflammatory responses trigger inflammatory oral cavity manifestations, especially in periodontal tissue leading to coagulation cascade and increased fibrinogen degradation confirming that COVID-19 could have an impact on periodontal tissue. ${ }^{35}$

\section{Discussion}

The papers included in this scoping review underline the role of certain molecules (ACE-2, furin, cathepsin, TMPRRS2...) in the mechanism of entry of SARS-CoV-2 into cells; these molecules are found at a high level in periodontal tissues, particularly in patients with periodontitis. In addition, periodontopathic bacteria could play a direct role in the mechanism of entry of SARS-CoV-2 by cleaving the S-protein, and the cytokines produced during periodontitis ${ }^{43}$ could add to the cytokine storm found in the severe forms of COVID-19. Several authors also note that the periodontal pockets could constitute a reservoir for SARS-CoV-2 allowing the virus to enter at the systemic level and to be present at the 
salivary level. Taken together, this suggests a link between periodontitis and COVID-19. This leads us to wonder whether or not periodontal diseases should be considered as a risk factor for COVID-19, at the same level as diabetes, cardiovascular diseases, etc. More generally, given that periodontal treatment allows a reduction in periodontopathic bacteria and in the local and systemic inflammation state, ${ }^{44-46}$ it could consequently reduce the inflammation state in COVID-19 patients. It thus appears that the treatment of periodontitis could be part of a strategy to prevent the development of severe forms of COVID-19.

Regarding clinical periodontal manifestations of COVID-19, as of today, there is an insufficient number of clinical cases with confirmed COVID-19 to draw any conclusions. Gingival inflammation appears to be common in patients suspected of having COVID-19, but there is insufficient evidence that this gingival inflammation is secondary to CoV-2 SARS infection and it is widely known that gingivitis is very common. ${ }^{47}$ However, lesions of the oral cavity have been reported in COVID-19, such as vesiculobullous lesions. ${ }^{12,48}$ In this context, the potential risk of periodontal manifestations related to COVID-19 needs to be further explored.

Overall, this scoping review, although being mostly composed of hypotheses, presents possible biological mechanisms behind the relationship between SARS-CoV-2 and periodontal diseases that seem promising for future studies, especially clinical or experimental research. In addition, it should be noted that published data currently does not include new variants and these should be investigated to better understand their impact at the periodontal level.

\section{Conflict of Interest}

None declared.

\section{Acknowledgments}

The authors thank Philip Robinson (DRCI, Hospices Civils de Lyon) for help in manuscript preparation.

\section{References}

1 Coronaviridae Study Group of the International Committee on Taxonomy of Viruses. The species severe acute respiratory syndrome-related coronavirus: classifying 2019-nCoV and naming it SARS-CoV-2. Nat Microbiol 2020;5(4):536-544

2 Zhu N, Zhang D, Wang W, et al. China Novel Coronavirus Investigating and Research Team. A novel coronavirus from patients with pneumonia in China, 2019. N Engl J Med 2020;382(8):727-733

3 WHO Coronavirus Disease (COVID-19) Dashboard. Accessed February 17, 2021 at: https://covid19.who.int

4 CDC. COVID-19 and Your Health. Centers for Disease Control and Prevention. Accessed January 21, 2021 at: https://www. cdc.gov/coronavirus/2019-ncov/need-extra-precautions/ people-with-medical-conditions.htm

5 Mark Bartold P, Mariotti A. The future of periodontal-systemic associations: raising the standards. Curr Oral Health Rep 2017;4(3):258-262

6 Vincent RR, Appukuttan D, Victor DJ, Balasundaram A. Oxidative stress in chronic periodontitis patients with type II diabetes mellitus. Eur J Dent 2018;12(2):225-231
7 Glurich I, Acharya A. Updates from the evidence base examining association between periodontal disease and type 2 diabetes mellitus: current status and clinical relevance. Curr Diab Rep 2019;19(11):121

8 Wang J, Yang $\mathrm{X}$, Zou X, Zhang Y, Wang J, Wang Y. Relationship between periodontal disease and lung cancer: a systematic review and meta-analysis. J Periodontal Res 2020;55(5):581-593

9 Xiao L, Zhang Q, Peng Y, Wang D, Liu Y. The effect of periodontal bacteria infection on incidence and prognosis of cancer: a systematic review and meta-analysis. Medicine (Baltimore) 2020;99(15):e19698

10 Heji ES, Bukhari AA, Bahammam MA, Homida LA, Aboalshamat KT, Aldahlawi SA. Periodontal disease as a predictor of undiagnosed diabetes or prediabetes in dental patients. Eur J Dent 2021;15(2):216-221. Doi:10.1055/s-0040-1719208

11 Tricco AC, Lillie E, Zarin W, et al. PRISMA extension for scoping reviews (PRISMA-ScR): checklist and explanation. Ann Intern Med 2018;169(7):467-473

12 Kadkhodazadeh M, Amid R, Moscowchi A. Does COVID-19 affect periodontal and peri-implant diseases? J Long Term Eff Med Implants 2020;30(1):1-2

$13 \mathrm{Xu} \mathrm{H}$, Zhong L, Deng J, et al. High expression of ACE2 receptor of 2019-nCoV on the epithelial cells of oral mucosa. Int J Oral Sci 2020;12(1):8

14 Zhong M, Lin B, Gao H, et al. Significant expression of FURIN and ACE2 on oral epithelial cells may facilitate the efficiency ofSARSCoV-2 entry. BioRxiv 2020 doi:10.1101/2020.04.18.047951

15 Botros N, Iyer P, Ojcius DM. Is there an association between oral health and severity of COVID-19 complications? Biomed J 2020;43(4):325-327

16 Badran Z, Gaudin A, Struillou X, Amador G, Soueidan A. Periodontal pockets: A potential reservoir for SARS-CoV-2? Med Hypotheses 2020;143:109907

17 Sahni V, Gupta S. COVID-19 \& Periodontitis: the cytokine connection. Med Hypotheses 2020;144:109908

18 Madapusi Balaji T, Varadarajan S, Rao USV, et al. Oral cancer and periodontal disease increase the risk of COVID 19? A mechanism mediated through furin and cathepsin overexpression. Med Hypotheses 2020;144:109936

19 Gupta S, Sahni V. The intriguing commonality of NETosis between COVID-19 \& periodontal disease. Med Hypotheses 2020;144:109968

20 Patel J, Woolley J. Necrotizing periodontal disease: Oral manifestation of COVID-19. Oral Dis 2021;27 (Suppl 3):768-769 doi:10.1111/odi.13462

21 Pfützner A, Lazzara M, Jantz J. Why do people with diabetes have a high risk for severe COVID-19 disease?-a dental hypothesis and possible prevention strategy. J Diabetes Sci Technol 2020;14(4):769-771

22 Pitones-Rubio V, Chávez-Cortez EG, Hurtado-Camarena A, González-Rascón A, Serafín-Higuera N. Is periodontal disease a risk factor for severe COVID-19 illness? Med Hypotheses 2020;144:109969

23 Sampson V, Kamona N, Sampson A. Could there be a link between oral hygiene and the severity of SARS-CoV-2 infections? Br Dent J 2020;228(12):971-975

24 Bertolini M, Pita A, Koo S, Cardenas A, Meethil A. Periodontal disease in the COVID-19 era: potential reservoir and increased risk for SARS-CoV-2. Pesqui Bras Odontopediatria Clin Integr 2020;20(suppl 1):e0134

25 Pedrosa MDS, Neves Nogueira F. COVID-19 and diabetes: what should we expect? J Diabetes Sci Technol 2020;14(6):1133-1134

26 Sakaguchi W, Kubota N, Shimizu T, et al. Existence of SARSCoV-2 entry molecules in the oral cavity. Int J Mol Sci 2020;21(17):E6000 
27 Kara C, Çelen K, Dede FÖ, Gökmenoğlu C, Kara NB. Is periodontal disease a risk factor for developing severe Covid-19 infection? The potential role of Galectin-3. Exp Biol Med (Maywood) 2020;245(16):1425-1427

28 Mancini L, Quinzi V, Mummolo S, Marzo G, Marchetti E. Angiotensin-converting enzyme 2 as a possible correlation between COVID-19 and periodontal disease. Appl Sci (Basel) 2020;10(18):6224

29 Räisänen IT, Umeizudike KA, Pärnänen P, et al. Periodontal disease and targeted prevention using aMMP-8 point-of-care oral fluid analytics in the COVID-19 era. Med Hypotheses 2020;144:110276

30 Elisetti N. Periodontal pocket and COVID-19: could there be a possible link? Med Hypotheses 2021;146:110355

31 Gupta S, Mohindra R, Chauhan PK, et al. SARS-CoV-2 detection in gingival crevicular fluid. J Dent Res 2021;100(2):187-193

32 Takahashi Y, Watanabe N, Kamio N, Kobayashi R, Iinuma T, Imai K. Aspiration of periodontopathic bacteria due to poor oral hygiene potentially contributes to the aggravation of COVID-19. J Oral Sci 2020;63(1):1-3

33 Larvin H, Wilmott S, Wu J, Kang J. The impact of periodontal disease on hospital admission and mortality during COVID-19 pandemic. Front Med (Lausanne) 2020;7-604980

34 Fernandes Matuck B, Dolhnikoff M, Maia GVA, et al. Periodontal tissues are targets for Sars-Cov-2: a post-mortem study. J Oral Microbiol 2020;13(1):1848135

35 Gofur N. Impact of SARS-CoV-2 on periodontal tissue manifestation. J Int Oral Health 2020;12(8):90-92

36 Roganović JR. MicroRNA-146a and -155, upregulated by periodontitis and type 2 diabetes in oral fluids, are predicted to regulate SARS-CoV-2 oral receptors genes. J Periodontol 2020;10.1002/JPER.20-0623 doi:10.1002/JPER.20-0623

37 Esteves-Lima RP, Pereira Gde M. Impact of periodontal condition for individuals with COVID-19. J Oral Res 2020:20-22
38 Vieira AR. Oral manifestations in coronavirus disease 2019 (COVID-19). Oral Dis 2021;27 (Suppl 3):770 doi:10.1111/ odi. 13463

39 Al-Bayaty FH. Impact of COVID-19 on periodontal therapy: an overview. J Oral Res 2020;Covid-19 S2(1):10-13 doi:10.17126/ joralres.2020.044

40 Daly J, Black EAM. The impact of COVID-19 on population oral health. Community Dent Health 2020;37(4):236-238

41 Iranmanesh B, Khalili M, Amiri R, Zartab H, Aflatoonian M. Oral manifestations of COVID-19 disease: a review article. Dermatol Ther (Heidelb) 2021;34(1):e14578

42 Frankenberger $\mathrm{R}$. Oral immunocompetence in the corona pandemic vs. system relevance of dentistry. Gesund Oekon Qual Manag 2020;25(5):256-263 doi:10.1055/a-1286-8376

43 Ramadan DE, Hariyani $\mathrm{N}$, Indrawati R, Ridwan RD, Diyatri I. Cytokines and chemokines in periodontitis. Eur J Dent 2020;14(3):483-495

44 Demmer RT, Trinquart L, Zuk A, et al. The influence of anti-infective periodontal treatment on C-reactive protein: a systematic review and meta-analysis of randomized controlled trials. PLoS One 2013;8(10):e77441

45 Baeza M, Morales A, Cisterna C, et al. Effect of periodontal treatment in patients with periodontitis and diabetes: systematic review and meta-analysis. J Appl Oral Sci 2020;28:e20190248

46 Delbove T, Gueyffier F, Juillard L, et al. Effect of periodontal treatment on the glomerular filtration rate, reduction of inflammatory markers and mortality in patients with chronic kidney disease: a systematic review. PLoS One 2021;16(1):e0245619

47 Pihlstrom BL, Michalowicz BS, Johnson NW. Periodontal diseases. Lancet 2005;366(9499) :1809-1820

48 Martín Carreras-Presas C, Amaro Sánchez J, López-Sánchez AF, Jané-Salas E, Somacarrera Pérez ML. Oral vesiculobullous lesions associated with SARS-CoV-2 infection. Oral Dis 2021; 27 Suppl 3:710-712 doi:10.1111/odi.13382 